\title{
PUMICE LAYER: A SOLUTION TO DIMINISH THERMAL ON HORIZONTAL LEFTOVER PLACE IN ROOFTOP
}

\author{
Danny Santoso Mintorogo ${ }^{1 *}$, Wanda Widigdo ${ }^{2}$, Anik Juniwati ${ }^{3}$ \\ ${ }_{1,2,3}$ Department of Architecture, Petra Christian University \\ Jalan Siwalankerto no. 121-131, Surabaya, Indonesia \\ *Corresponding author; Email: dannysm@petra.ac.id
}

\begin{abstract}
There are many ways to solve thermal on buildings, such as the installation of horizontal and vertical sun-shading devices on four-direction facades. However, rooftops are often ignored. In low-rise to high-rise buildings' rooftop, there are leftover places exposed to solar heat radiation all day. Some rooftop places are equipped with polymer thermal roof insulation, and some are even without outer thermal insulation. The research aims to find a solution to diminish the horizontal thermal radiation by using eco-friendly material, pumice, as an outer thermal insulation. Exploiting method was used on one roof model as a conventional rooftop (without outer insulation), and another as a modified rooftop model covered with pumice. Couple HOBO data logger U12-012 temperature sensors were used to measure rooftop surface temperatures and room model temperatures. Results show that the thermal radiation were blocked efficiently: $26^{\circ} \mathrm{C}$ on pumice covered rooftop. It saved $8.4^{\circ} \mathrm{C}$ room temperature.
\end{abstract}

Keywords: Pumice; thermal; leftover rooftop spaces.

\section{INTRODUCTION}

Over the last decades due to the high demand, small shops and office spaces have been built quickly in the urban and suburban areas of Surabaya. They are usually three to four-story buildings; the first and second floor are used for business, while the third and four are for living areas (see figure $1 \mathrm{~B} \& \mathrm{C}$ ). But mostly shop-houses are used for business purposes only. The rooftop of shop-houses are mostly concrete constructed horizontally, and built without any external insulation layers on the rooftops. The rooftop space is usually a storage of water tanks and outdoor air conditioning units with leftover spaces (empty spaces), see figure $1 \mathrm{~A}$.

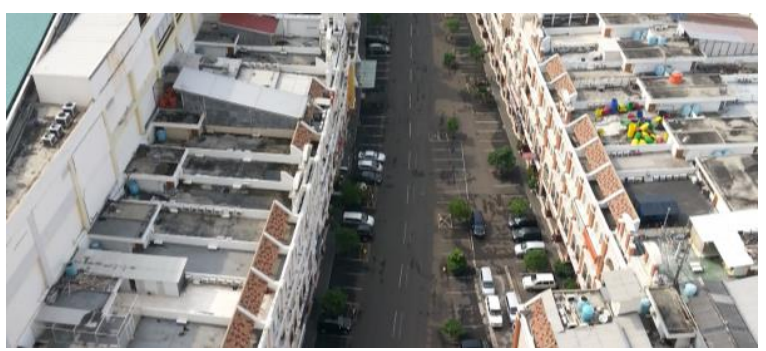

(A)

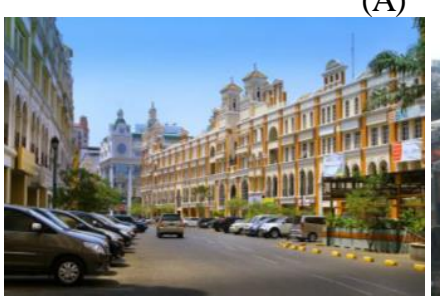

(B)

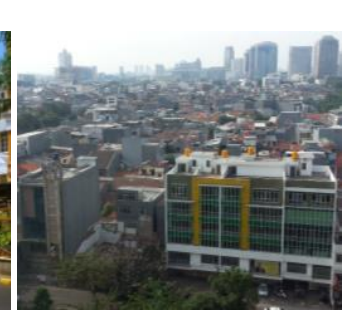

(C)
Fig. 1. Horizontal Rooftops (A \& C), Shop/Office House Façade (B)
Many shops or office houses have a big leftover place on the rooftop which are exposed to solar radiation every day, month and year. Each flat or tilted outer concrete rooftop built responds to and suffers from climate zones, thermal roofs, and solar irradiance, affecting room temperature beneath the uninsulated flat rooftop. The horizontal solar irradiance in the tropical zone (Surabaya $7^{\circ} 17^{\prime}-21^{\prime}$ ) on the roof is greater than vertical solar irradiance on the façade. By using online solar irradiance calculator that collected solar insolation data for 22 years on all cities around the world, we could obtain the solar insolation data for all directions and time (http://www.solarelectricityhandbook.com/solar-calculator.html). Based on the solar irradiance calculator, the average amount of solar insolation from January to July ranges from 4.68 to $4.98 \mathrm{kWh} / \mathrm{m}^{2} /$ day, and fluctuates from 5.48 to $5.97 \mathrm{kWh} / \mathrm{m}^{2} /$ day from July to November except in December ( $4.9 \mathrm{kWh} / \mathrm{m}^{2} /$ day) (see figure 2). The yearly average of solar insulation is $4.71 \mathrm{kWh} / \mathrm{m}^{2}$ per day on solar-calculator, meanwhile the result from the solar insolation experiment was $5.1 \mathrm{kWh} / \mathrm{m}^{2}$ per day (figure 4) (Mintorogo, 2009). If one shop house's dimension is 5 meter $\mathrm{x} 20$ meter, then the flat rooftop will be $100 \mathrm{~m}^{2}$. This means $510 \mathrm{kWh} /$ day of thermal solar insulation affects the room thermal beneath the rooftop. This phenomena would be different if the solar insulation hit the Photovoltaic panels (PV) laid on the flat rooftop which attracts photons and releases electrons in the form of electric current (renewable energy) (Carl, 2014). 


\begin{tabular}{|c|c|c|c|c|c|}
\hline & & & rage & $\begin{array}{l}\text { aba } \\
\text { lar } \\
\text { jure }\end{array}$ & olation \\
\hline & & & $\begin{array}{l}\text { sured } \mathrm{i} \\
\text { horiz }\end{array}$ & $\begin{array}{l}\text { Wh/n } \\
\text { tal st }\end{array}$ & $\begin{array}{l}\text { y onto a } \\
\text { e: }\end{array}$ \\
\hline Jan & Feb & Mar & Apr & May & Jun \\
\hline 4.69 & 4.75 & 4.87 & 4.92 & 4.87 & 4.68 \\
\hline Jul & Aug & Sep & Oct & Nov & Dec \\
\hline 4.98 & 5.48 & 5.97 & 5.85 & 5.21 & 4.90 \\
\hline
\end{tabular}

Fig. 2. Digital Solar Irradiance of the Average Horizontal Solar Insolation in Surabaya per-day $\left(\mathrm{kWh} / \mathrm{m}^{2} /\right.$ day $)$ (Source: http://solarelectricityhandbook.com/solar-irradiance. html)

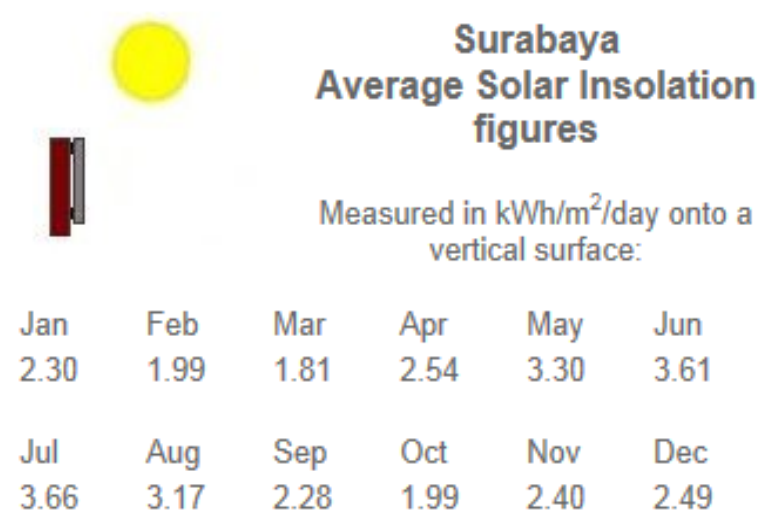

Fig. 3. Digital Solar Irradiance of the Average Vertical Solar Insolation in Surabaya per-day $\left(\mathrm{kWh} / \mathrm{m}^{2} /\right.$ day $)$ (Source: http://solarelectricityhandbook.com/solar-irradiance. html)

$\begin{array}{cccccc}\text { Jan } & \text { Feb } & \text { Mar } & \text { Apr } & \text { May } & \text { Jun } \\ 4.18 & 3.93 & 4.15 & 4.45 & 4.4 & 4.5 \\ & & & & & \\ \text { Jul } & \text { Aug } & \text { Sep } & \text { Oct } & \text { Nov } & \text { Dec } \\ 4.85 & 5.38 & 5.83 & 5.78 & 5.0 & 4.13\end{array}$

Fig. 4. Measured In-situ Solar Irradiance of the Average Horizontal Solar Insolation in Surabaya per-day $\left(\mathrm{kWh} / \mathrm{m}^{2} /\right.$ day) (Source: Mintorogo, 2009)

The research objective is to look for ecofriendly, sustainable insulation that can be applied to outdoor rooftop insulation and keep our environment clean and free of chemical substances. Celik (2016) stated that pumice has its physical volcanic evolution: permeable and low thermal conductivity that has better thermal solution for roof insulation. A roof insulation can be made by building up roofing membranes made of hot-tar, single-ply, polyurethane substances, asphalt, and bitumen. However, those are not natural insulation materials, which means they are not environmentally-friendly (See figure 5A \& 5B).
(A)

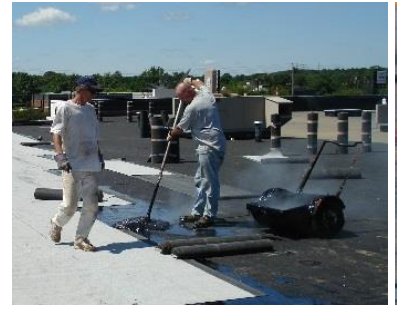

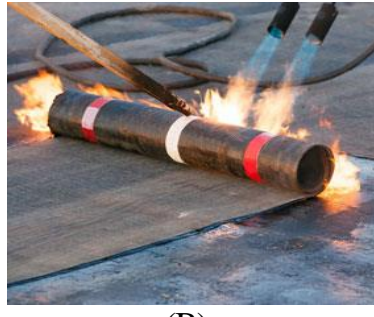

(B)
Fig. 5. Applying Hot-Tar on Insulation Membranes (A), Constructed Built Up Roofing (BUR) (B). (Source: google.com)

\section{MATERIALS AND METHOD}

\section{Materials}

Pumice grains are used as outdoor eco-insulation on horizontal flat concrete in this research. Pumice is very light and porous, it is a natural igneous rock that is formed from glassy volcanic eruption lava which solidifies, and is an easy adsorbent matter to water and air (Kitis et al., 2007). Typically, pumice is lightcoloured and non-crystalline. Figure 6A shows pumice obtained from Lombok's (Eastern Indonesia) Mountain areas. The size ranges from $3 \mathrm{~cm}$ to $6 \mathrm{~cm}$ (figure 6B). The porosity of Pumice reaches $90 \%$ of its body. Pumice also floats on water (Ismail et al., 2014).

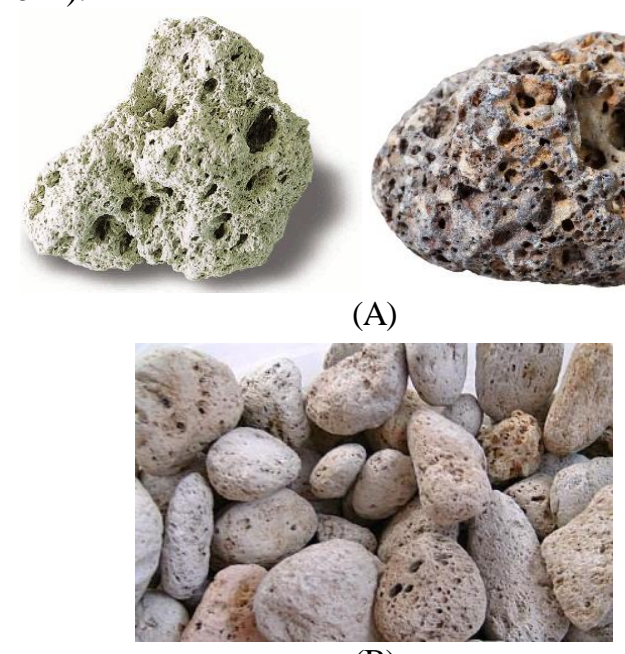

(B)

Fig. 6. Stand-alone Igneous Rock of Pumice; light and dark color (A), Pumices in Blocks (B). (Source: https://www. google.com/search?q=pumice\&tbm=)

\section{Experimental Models}

There were two experimental models: 1) one model (bare rooftop) was as a reference: fundamental state, no insulations applied. 2) The other model (modified rooftop) was filled with pumice as an outer eco insulation (see figure 7A and B). Both models 
measured the temperatures: 1). the reference rooftop surface temperature and the room model temperature. 2) The pumice rooftop surface temperature and the pumice rooftop room temperature (figure $7 \mathrm{C}$ ).
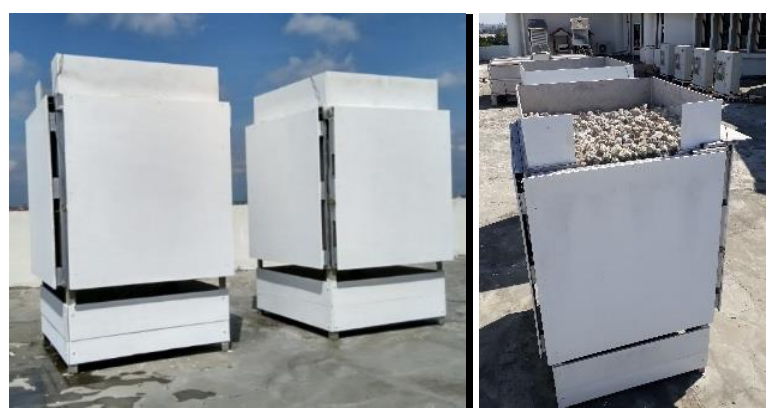

(A)

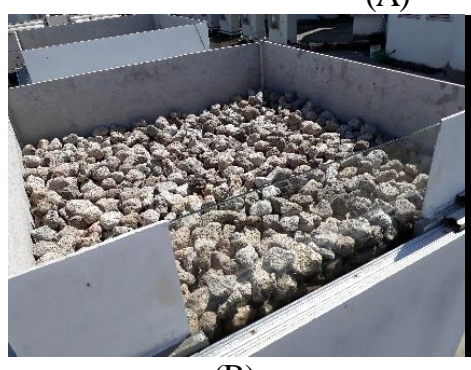

(B)

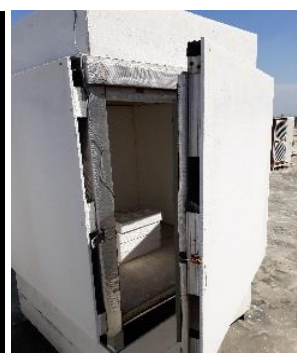

(C)
Fig. 7. Two Experimental Models (A), Pumice Rooftop (One model) (B), Measured Room Model (C)

Both models had the same dimension: 1) The room models were $1 \mathrm{mx} 1 \mathrm{~m} \mathrm{x} 1 \mathrm{~m}$. 2) The flat rooftop was $0.2 \mathrm{~m}$ in height. 3) The bottom model was lifted $0.5 \mathrm{~m}$ from the ground (avoid reflected roof thermal). 4) Styrofoam sheets with $0.02 \mathrm{~m}$ thickness were used to cover all sides of the experimental model including the interior and the bottom part. 5) Cement boards (Kalsi board) with $4 \mathrm{~mm}$ thickness were used to cover all sides of the measured models. 6) Finally, aluminium foil sheets were pasted on all sides of the experimental models (figure 8A).

\section{Measured Tools}

Measured tools were from ONSET-USA, HOBO Data Logger U12-012, and thermocouple probe. 4 units of Data Loggers were used to record the surface and room model temperatures. One unit HOBO data logger measured the surface rooftop temperature (thermocouple probe), and another measured room model temperature with an attached sensor on Hobo tool (figure 8A \& 8B).

\section{Methods}

The research is an experimental in situ on the seventh floor of the horizontal flat concrete rooftop at Petra Christian University. Two types of rooftop models (conventional and covered pumice) were measured at the same time that running for months. Several significant thermal data were obtained thermal in critical months like in June (less thermal on rooftops due to position of the sun on Northern $23.5^{\circ}$ ) and September/October (the hottest month due to position of the sun above the equator). The results of the thermal were: 1) conventional model roof surface temperature and room temperature. 2) coveredpumice model roof surface temperature and room temperature.

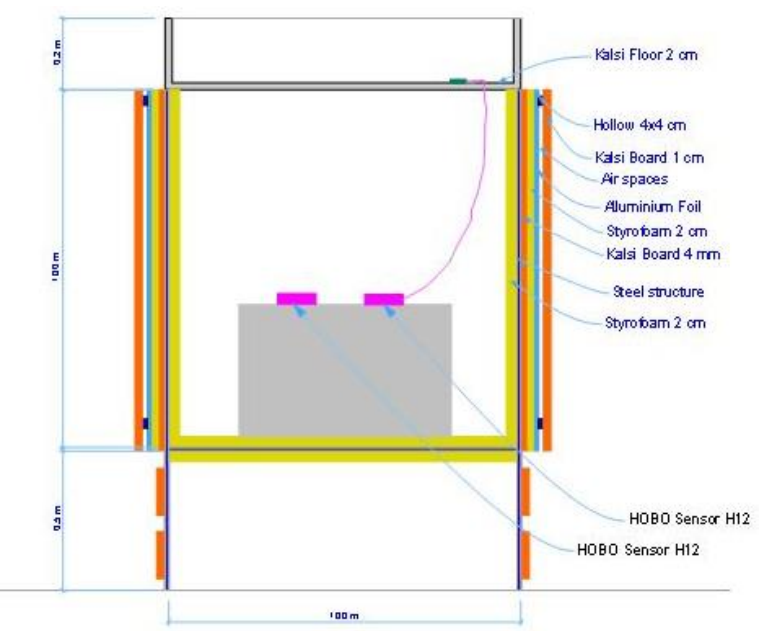

(A)

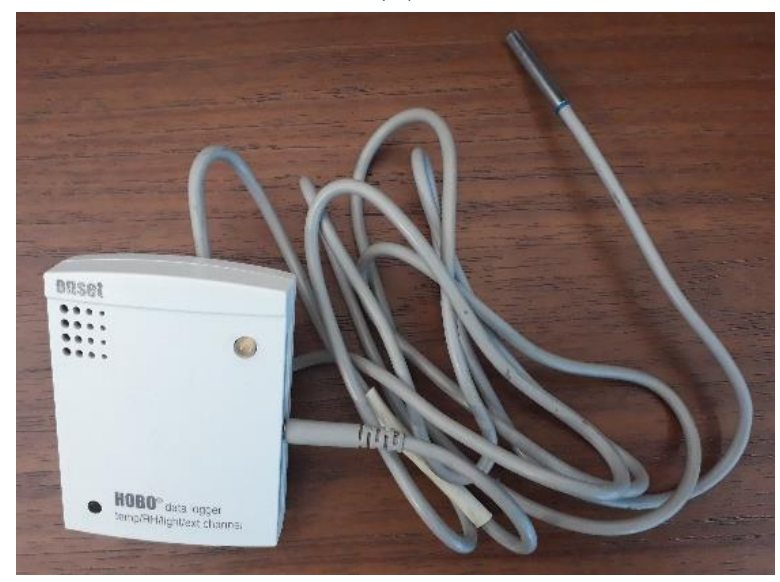

(B)

Fig. 8. Experimental Model dimension (A), Measured Tool (Hobo Data Logger U12-012 and Thermocouple Probe) (B)

\section{RESULTS AND DISCUSSIONS}

With pumice as outer insulation sheltered on rooftop, the room temperature must be cut down several degrees Celsius. Table 1 shows the roof surface temperature on bare rooftop during June 2018 reached $48.9^{\circ} \mathrm{C}$ at noon. The rooftop surface temperature can be cut down by $23.5^{\circ} \mathrm{C}$ by putting pumice with $0.015 \mathrm{~m}$ thickness on top of the flat roof. By cooling down the roof surface temperature to 
$23.5^{\circ} \mathrm{C}$, room thermal on pumice model was cooled down by $6.4^{\circ} \mathrm{C}$ (see table 2). Table 1 also shows that from 11am to $1 \mathrm{pm}$ the rooftop surface temperature at reference model increased by $3^{\circ} \mathrm{C}\left(45.9\right.$ to $\left.48.9^{\circ} \mathrm{C}\right)$. Meanwhile, the roof surface temperature covered with pumice materials increased by $1.4^{\circ} \mathrm{C}$ merely, and roof surface thermal remains stable throughout the day (morning-evening-night). The rooftop surface temperature with pumice decreased by $3.4^{\circ} \mathrm{C}$ from 6 $\mathrm{pm}$ to $5 \mathrm{am}$. Meanwhile, the surface temperature at reference model started to decrease by $4.7^{\circ} \mathrm{C}$ from 6 $\mathrm{pm}$ to $5 \mathrm{am}$. Conventional roof surface (no materials on the rooftop) releases stored thermal on the roof faster than the pumice roof (preventing thermal outflow) during the night (cool night radiation). However, pumice roof achieves better thermal load on rooftop during the day (lower and stable thermal loads) (table $1 \& 2$ ). The released rooftop thermal load at pumice roof was $-2.3^{\circ} \mathrm{C}$ (table 1 ) and $-1.2^{\circ} \mathrm{C}$ (table 2) at room temperature at 6 am with comparison to conventional rooftop. Overall, the average thermal performance on pumice rooftop was $4.1^{\circ} \mathrm{C}$, and the average room thermal accomplishment was $1^{\circ} \mathrm{C}$.

Table 1. Roof Surface Temperature Differences (June 2018)

\begin{tabular}{|c|c|c|c|}
\hline Time & $\begin{array}{c}\text { Reference Model } \\
\text { Surface } \\
{ }^{\circ} \mathbf{C} \\
\end{array}$ & $\begin{array}{c}\text { Pumice Model } \\
\text { Surface } \\
{ }^{\circ} \mathbf{C} \\
\end{array}$ & $\begin{array}{c}\text { Temperature } \\
\text { Differences } \\
{ }^{\circ} \mathrm{C} \\
\end{array}$ \\
\hline 6 & 22.6 & 24.8 & -2.3 \\
\hline 7 & 23.8 & 24.6 & -0.8 \\
\hline 8 & 26.2 & 24.3 & 2.0 \\
\hline 9 & 30.4 & 24.4 & 6.0 \\
\hline 10 & 39.8 & 22.6 & 17.3 \\
\hline 11 & 45.9 & 24.0 & 21.9 \\
\hline 12 & 48.9 & 25.4 & 23.5 \\
\hline 13 & 48.1 & 26.4 & 21.8 \\
\hline 14 & 44.4 & 26.7 & 17.7 \\
\hline 15 & 38.7 & 26.8 & 11.9 \\
\hline 16 & 31.9 & 26.7 & 5.2 \\
\hline 17 & 26.6 & 26.3 & 0.4 \\
\hline 18 & 24.6 & 25.8 & -1.2 \\
\hline 19 & 23.5 & 25.4 & -1.9 \\
\hline 20 & 23.0 & 25.1 & -2.1 \\
\hline 21 & 22.8 & 24.7 & -1.9 \\
\hline 22 & 22.4 & 24.4 & -2.0 \\
\hline 23 & 22.0 & 24.2 & -2.2 \\
\hline 24 & 21.8 & 23.9 & -2.1 \\
\hline 1 & 21.3 & 23.7 & -2.3 \\
\hline 2 & 20.9 & 23.3 & -2.5 \\
\hline 3 & 20.6 & 23.1 & -2.5 \\
\hline 4 & 20.4 & 22.8 & -2.3 \\
\hline 5 & 19.9 & 22.4 & -2.5 \\
\hline Average & 28.8 & 24.7 & 4.1 \\
\hline
\end{tabular}

Table 2. Room Temperature Differences (June 2018)

\begin{tabular}{cccc}
\hline Time & $\begin{array}{c}\text { Reference Model } \\
\text { Room } \\
{ }^{\circ} \mathbf{C}\end{array}$ & $\begin{array}{c}\text { Pumice Model } \\
\text { Room } \\
{ }^{\circ} \mathbf{C}\end{array}$ & $\begin{array}{c}\text { Temperature } \\
\text { Differences } \\
{ }^{\circ} \mathbf{C}\end{array}$ \\
\hline 6 & 23.7 & 24.9 & -1.2 \\
7 & 24.0 & 24.9 & -0.8 \\
8 & 25.9 & 25.7 & 0.2 \\
9 & 29.5 & 27.3 & 2.1 \\
10 & 30.3 & 26.4 & 3.9 \\
11 & 33.2 & 27.8 & $\mathbf{5 . 4}$ \\
12 & 35.2 & 28.8 & $\mathbf{6 . 4}$ \\
13 & 35.9 & 29.4 & $\mathbf{6 . 5}$ \\
14 & 35.0 & 29.5 & 5.5 \\
15 & 32.9 & 29.2 & 3.7 \\
16 & 30.7 & 28.7 & 2.0 \\
17 & 28.4 & 27.9 & 0.5 \\
18 & 26.6 & 27.0 & -0.4 \\
19 & 25.6 & 26.3 & -0.7 \\
20 & 24.9 & 25.8 & -0.9 \\
21 & 24.5 & 25.3 & -0.9 \\
22 & 24.2 & 25.0 & -0.8 \\
23 & 23.8 & 24.7 & -0.8 \\
24 & 23.5 & 24.3 & -0.9 \\
1 & 23.1 & 24.0 & -0.9 \\
2 & 22.6 & 23.6 & -1.0 \\
3 & 22.3 & 23.3 & -1.0 \\
4 & 21.9 & 22.9 & -1.0 \\
5 & 21.6 & 22.7 & -1.0 \\
Average & $\mathbf{2 7 . 1}$ & $\mathbf{2 6 . 1}$ & $\mathbf{1 . 0}$ \\
\hline & & &
\end{tabular}

Table 3 shows the heat of reference roof model at 11 o'clock reached the highest temperature at $53.5^{\circ} \mathrm{C}$ in September due to the high concentration of solar radiation on the flat surface. As a comparison, the highest roof temperature of of the reference model rooftop in June 2018 was only $48.9^{\circ} \mathrm{C}$ at noon (table 1 ). So, there was $4.6^{\circ} \mathrm{C}$ flat rooftop heat flux difference due to the position of the sun in June and September (table $1 \& 3$ ).

When the rooftop was covered with pumice layers resulted in lower roof temperature by $27.4^{\circ} \mathrm{C}$, meanwhile the rooftop temperature of the reference rooftop model was $53.5^{\circ} \mathrm{C}$ at 11 am. Consequently, it demonstrates that pumicelayered rooftop could decrease huge thermal by $26.1^{\circ} \mathrm{C}$ (11 am), 22.5 (12 noon), 23.5 (1 pm), $19.5^{\circ}(2 \mathrm{pm}), 17.2^{\circ}(3 \mathrm{pm}), 10.3^{\circ} \mathrm{C}(4 \mathrm{pm})$ respectively. In addition, the pumice-layered rooftop gradually began to lose small amount of stored roof heat to the cool sky (after sun-set) at $6 \mathrm{pm}$ to 6 am (the next morning). The pumice rooftop lost less heat to conventional rooftop by about $3^{\circ} \mathrm{C}$. 
Table 3. Roof Surface Temperature Differences (September 2018)

\begin{tabular}{|c|c|c|c|}
\hline Time & $\begin{array}{l}\text { Reference Model } \\
\text { Temperature } \\
\left({ }^{\circ} \mathrm{C}\right)\end{array}$ & $\begin{array}{c}\text { Pumice Model } \\
\text { Temperature } \\
\left({ }^{\circ} \mathrm{C}\right)\end{array}$ & $\begin{array}{c}\text { Temperature } \\
\text { Differences } \\
\left({ }^{\circ} \mathrm{C}\right)\end{array}$ \\
\hline 6 & 20.9 & 23.4 & -2.5 \\
\hline 7 & 22.3 & 23.4 & -1.1 \\
\hline 8 & 25.3 & 23.9 & 1.4 \\
\hline 9 & 30.1 & 25.0 & 5.1 \\
\hline 10 & 46.9 & 26.3 & 20.6 \\
\hline 11 & 53.5 & 27.4 & 26.1 \\
\hline 12 & 50.5 & 28.0 & 22.5 \\
\hline 13 & 51.8 & 28.3 & 23.5 \\
\hline 14 & 48.1 & 28.6 & 19.5 \\
\hline 15 & 45.8 & 28.6 & 17.2 \\
\hline 16 & 38.7 & 28.4 & 10.3 \\
\hline 17 & 31.2 & 28.1 & 3.2 \\
\hline 18 & 27.4 & 27.6 & -0.2 \\
\hline 19 & 25.8 & 27.2 & -1.4 \\
\hline 20 & 24.4 & 27.0 & -2.6 \\
\hline 21 & 24.1 & 26.6 & -2.6 \\
\hline 22 & 23.2 & 26.3 & -3.1 \\
\hline 23 & 22.9 & 25.9 & -2.9 \\
\hline 0 & 22.4 & 25.4 & -3.0 \\
\hline 1 & 21.7 & 25.0 & -3.3 \\
\hline 2 & 21.0 & 24.6 & -3.6 \\
\hline 3 & 21.7 & 24.1 & -2.5 \\
\hline 4 & 21.3 & 23.8 & -2.5 \\
\hline 5 & 20.5 & 23.5 & -3.0 \\
\hline Average & 30.9 & 26.1 & 4.8 \\
\hline
\end{tabular}

Table 4. Room Temperature Differences (September 2018)

\begin{tabular}{cccc}
\hline Time & $\begin{array}{c}\text { Reference Room } \\
\text { Temperature } \\
\left({ }^{\circ} \mathbf{C}\right)\end{array}$ & $\begin{array}{c}\text { Pumice Room } \\
\text { Temperature } \\
\left({ }^{\circ} \mathbf{C}\right)\end{array}$ & $\begin{array}{c}\text { Temperature } \\
\text { Differences } \\
\left({ }^{\circ} \mathbf{C}\right)\end{array}$ \\
\hline 6 & 23.5 & 25.0 & -1.5 \\
7 & 23.8 & 24.8 & -1.0 \\
8 & 26.6 & 25.7 & 0.9 \\
9 & 31.8 & 28.0 & 3.9 \\
10 & 36.5 & 30.4 & 6.1 \\
11 & 40.3 & 32.4 & $\mathbf{7 . 9}$ \\
12 & 42.1 & 33.7 & $\mathbf{8 . 4}$ \\
13 & 42.3 & 34.4 & $\mathbf{7 . 9}$ \\
14 & 41.3 & 34.5 & 6.8 \\
15 & 38.1 & 33.7 & 4.4 \\
16 & 35.4 & 32.7 & 2.7 \\
17 & 32.5 & 31.7 & 0.9 \\
18 & 30.4 & 30.8 & -0.5 \\
19 & 28.9 & 29.9 & -1.0 \\
20 & 28.0 & 28.9 & -1.0 \\
21 & 27.3 & 28.3 & -1.0 \\
22 & 26.6 & 27.8 & -1.2 \\
23 & 25.9 & 27.4 & -1.5 \\
0 & 25.3 & 26.9 & -1.6 \\
1 & 24.9 & 26.4 & -1.4 \\
2 & 24.4 & 25.9 & -1.5 \\
3 & 23.8 & 25.4 & -1.6 \\
4 & 23.2 & 24.9 & -1.7 \\
5 & 22.9 & 24.5 & -1.6 \\
Average & $\mathbf{3 0 . 2}$ & $\mathbf{2 8 . 9}$ & $\mathbf{1 . 3}$ \\
\hline & & &
\end{tabular}

\section{CONCLUSION}

The results show that in June or even September (the hottest month), a rooftop covered with pumice as an outer insulation on flat roof can affectively decrease more room thermal by $6.5^{\circ}$ to $8.4^{\circ} \mathrm{C}$ during the daytime compared to conventional flat bare rooftop (rooftop without insulation). Nevertheless, conventional rooftop will release roof mass thermal faster compared to the pumice rooftop, about $5^{\circ} \mathrm{C}$ during the night-time. Because of pumice very porous structure, the stored heat radiation can be released every second. Pumice layer on the top of the flat leftover roof sustained stable average thermal rooftop of around $26^{\circ} \mathrm{C}$ (an average temperature) during the day and room temperature of $29^{\circ} \mathrm{C}$ at night-time in September 2018.

\section{ACKNOWLEDGEMENT}

This study was conducted as a part of yearly fund research at the Department of Architecture, Petra Christian University-Indonesia, and was done in two academic semesters.

\section{REFERENCES}

Carl, C. (2014). Calculating Solar Photovoltaic Potential on Residential Rooftop in Kailua Kona, Hawaii. Graduate Thesis at University of Southern California.

Celik, S., Family, R., \& Pinar Menguc, M. (2016). Analysis of Perlite and Pumice Based Building Insulation Materials. Journal of Building Engineering, 6, 105-111

Ismail, A.I.M., El-Shafey, O.I., Amr, M.H.A., \& ElMaghraby, M.S. (2014). Pumice Characteristics and Their Utilization on the Synthesis of Mesoporous Minerals and on the Removal of Heavy Metals. International Scholarly Research Notices, Hindawi Publishing Corporation.

Kitis, M., Kaplan, S., Karakaya, E., Yigit, N.O. \& Civelekoglu, G. (2007). Adsorption of Natural Organic Matter from Waters by Iron coated Pumice. Chemosphere Journal, 66(1), 130-138.

Mintorogo, D.S. (2009). Solar Irradiance Data on Horizontal and Vertical in Surabaya-Indonesia. Research Report, Department of Architecture, Petra Christian University.

Mintorogo, D.S. (2014). Application of Pakis-Stem as Insulation to Control Heat Gain on Concrete Flat Roof. Thesis of Doctor of Philosophy at Faculty of Built Environment, Universiti Teknologi Malaysia. 